\title{
PENGEMBANGAN BUKU TEKS BERBASIS KARAKTER MENGGUNAKAN MULTIMEDIA SEBAGAI PENUNJANG MODEL TGT
}

\author{
Ariska Mandalika ${ }^{1}$, Bambang Yulianto $^{2}$, Setya Yuwana ${ }^{3}$ \\ ${ }^{1}$ Mahasiswa Program Pascasarjana, Prodi Pendidikan Dasar, Universitas Negeri Surabaya, \\ ${ }^{2 \& 3}$ Dosen Pascasarjana, Prodi Pendidikan Dasar, Universitas Negeri Surabaya \\ e-mail: ${ }^{1}$ ariskamandalika@gmail.com
}

Received : $\quad$ Maret 2018

Reviewed : April 2018

Accepted : Mei 2018

Published : $\quad$ Mei 2018

\section{ABSTRACT}

The general objective of the research is to develop text books thematic books using multimedia as a support TGT model for class V SD. Type of research is the development of design research 4D models consisting of defining, design, development, and deployment. In this study, textbook development adapted only to the stage of development, textbooks used only in pilot school, with no spread to the other schools. The data was obtained as follows: the percentage of the material feasibility of 100\%, 100\% eligibility presentation, linguistic appropriateness $96.42 \%$, and $95.83 \%$ grafic feasibility. All these categories, including quality category (very decent / good). Obtaining the results of observations of the activities of teachers and students respectively were $96.87 \%$ and $97.05 \%$. The response of teachers and students to the textbook was $100 \%$ and $96.10 \%$. Classical completeness of student learning outcomes of $85.71 \%$, the completeness criteria $\geq 70$. Based on the discussion of the results, we can conclude that in terms of products and the use of textbooks thematic use multimedia as a supporting character using TGT model fit for use.

Keywords: Character, Multimedia, Textbook Development, TGT.

\section{ABSTRAK}

Tujuan umum penelitian adalah mengembangkan buku buku teks tematik menggunakan multimedia sebagai penunjang model TGT untuk kelas V SD. Jenis penelitian yang dilakukan adalah penelitian pengembangan dengan desain model four- $D$ yang terdiri atas tahap pendefinisisan, perancangan, pengembangan, dan penyebaran. Dalam penelitian ini pengembangan buku teks diadaptasi hanya sampai pada tahap pengembangan, buku teks yang dikembangkan hanya digunakan pada sekolah ujicoba, tanpa disebar pada sekolah lain. Data hasil penelitian yang diperoleh sebagai berikut: persentase kelayakan materi $100 \%$, kelayakan penyajian $100 \%$, kelayakan kebahasaan $96.42 \%$, dan kelayakan kegrafikaan 95.83\%. Semua kategori tersebut termasuk kategori berkualitas (sangat layak/baik). Perolehan hasil observasi terhadap aktivitas guru dan siswa berturut-turut adalah $96.87 \%$ dan $97.05 \%$. Respon guru dan siswa terhadap buku teks adalah $100 \%$ dan $96.10 \%$. Ketuntasan klasikal hasil belajar siswa sebesar $85.71 \%$ yang sesuai dengan kriteria ketuntasan $\geq 70$. . Berdasarkan diskusi hasil penelitian, dapat disimpulkan bahwa segi produk dan penggunaan buku teks tematik berbasis karakter menggunakan multimedia sebagai penunjang model TGT layak digunakan.

Kata Kunci: Karakter, Multimedia, Pengembangan Buku Teks, TGT.

\section{PENDAHULUAN}

Pendidikan dasar merupakan jenjang pendidikan yang melandasi jenjang pendidikan menengah. Dalam UU No.2 tahun 1989, Pendidikan dasar diselenggarakan untuk mengembangkan sikap dan kemampuan serta memberikan pengetahuan dan keterampilan dasar yang diperlukan untuk hidup dalam masyarakat serta mempersiapkan peserta didik 
yang memenuhi persayaratan untuk mengikuti pendidikan menengah.

Sejalan dengan diterapkannya kurikulum 2013 maka model pembelajaran yang digunakan adalah tematik. Dalam pembelajaran tematik siswa tidak lagi belajar dalam bentuk mata pelajaran melainkan dikemas dalam tema. Kurikulum 2013 mengimplementasikan pendidikan berbasis karakter. Pelaksanaan pendidikan kepribadian atau karakter diatur dalam Peraturan Pemerintah Nomor 19 Tahun 2015 tentang Standar Nasional Pendidikan Pasal 7 Nomor 2 yakni mata pelajaran kewarganegaraan dan kepribadian pada setiap tingkat prndidikan dilaksanakan melalui muatan atau kegiatan agama, akhlak mulia, kewarganegaraan, bahasa, seni, dan budaya, dan pendidikan jasmani. Permendiknas tersebut menjelaskan bahwa salah satu cara mendidik kepribadian atau karakter mulalui muatan bahasa. Hal ini dipertegas denegan Peraturan Pemerintah Nomor 19 Tahun 2015 tentang Standar Nasional Pendidikan Pasal 6 nomor 6 yang menjelaskan bahwa kemampuan dan kegemaran baca tulis, kecakapan berhitung, serta kemapuan berkomunikasi menjadi titik penting dalam kurikulum dan silabus.

Ujung tombak berhasilnya pendidikan adalah guru. Dalam undang-undang nomor 14 tahun 2005 pasal 20 tentang guru dan dosen, bahwa guru melaksanakan tugas keprofesionalan berkewajiban untuk merencanakan pembelajaran, melaksanakan proses pembelajaran yang bermutu, serta menilai dan mengevaluasi hasil pembelajaran. Salah satu komponen digunakan guru dalam melaksanakan kegiatan belajar mengajar adalah buku. Komalasari (2010:3) menjelaskan bahwa agar pelayanan pendidikan yang selama ini diberikan kepada peserta didik mencapai sasaran optimal, maka pembelajaran didefinisikan sebagai suatu sistem atau proses membelajarakan subjek didik yang direncanakan, dilaksanakan, dan dievaluasi secara sistematis agar subjek didik dapat mencapai tujuan-tujuan pembelajaran secara efektif dan efisien.

Pada kurikulum 2013, pemerintah telah mempersiapkan buku panduan yaitu buku guru yang bersifat universal dan diberikan kepada guru yang ada di daerah. Hal tersebut dikhawatirkan buku guru tidak tepat guna karena setiap daerah memiliki kebutuhan dan karakteristik yang berbeda-beda dalam melaksanakan kegiatan belajar mengajar.

Berdasarkan hasil pengamatan dan diskusi yang dilaksanakan di SDN Megaluh Jombang khususnya kelas 5, ditemukan beberapa fakta tentang penggunaan buku guru meliputi (1) buku teks yang terbit kurang sesuai dengan lingkungan belajar siswa, (2) proses pembelajaran tematik yang dianjurkan belum dilaksanakan sepenuhnya, guru cenderung menyampaikan satu per satu materi ajar, (4) penggunaan tema sebagai acuan pembelajaran tidak digunakan sepenuhnya, (5) materi yang masih singkat dan kurang lengkap mengakibatkan siswa kurang mampu mengerjakan latihan soal, (6) penyampaian materi secara lisan dan tidak disertai dengan peraga atau media; (7) penggunaan bahasa yang kurang komunikatif, (8) tugas yang diberikan diadopsi langsung dari buku teks tanpa ada upaya untuk menghubungakan dengan karakteristik lingkungan belajar, tujuan dan kompetensi yang harus dicapai siswa, (9) guru kurang berinovasi, sehingga kegiatan belajar mengajar terkesan monoton dan kurang menyenangkan, (10) guru terkadang sering lupa untuk menekankan karakter sehingga nilai-nilai tersebut hanya disampaikan secara lisan berdasarkan kemapuan guru tersebut.

Berdasarkan latar belakang di atas, maka dirumuskan suatu permasalahan sebagai berikut. (a) bagaimanan proses pengembangan buku teks tematik berbasis karakter dengan multimedia sebagai penunjang model TGT?; (b) bagaimana kualitas buku teks tematik berbasis karakter dengan multimedia sebagai penunjang model TGT yang dikembangkan?; (c) bagaimana implementasi pengembangan buku teks tematik berbasis karakter dengan multimedia sebagai penunjang model TGT yang dikembangkan?.

Setiap peserta didik mempunyai karakteristik yang unik, mereka memiliki gaya belajar yang bermacammacam. Guru hendaknya mampu menyajikan materi pelajaran dengan memperhatikan masing-masing karakteristik peserta didiknya. Menurut DePotter \& Hernachi (2002:78 ) gaya belajar ada tiga karakteristik yaitu : visual (belajar dengan cara melihat), auditori (belajar dengan cara mendengar), dan kinestetik (belajar dengan cara bergerak, bekerja, dan menyentuh).

Peserta didik sekolah dasar merupakan anak yang berada pada usia 7-11 tahun. Menurut teori Perkembangan Kognitif Piaget pebelajar dengan umur 7-11 tahun memasuki tahap operasional konkrit. Pebelajar sekolah dasar khususnya kelas 5 memiliki karakteristik senang bermain dan senang bekerja dalam kelompok. Dari pergaulannya dengan kelompok sebaya, peserta didik akan belajar aspek-aspek penting dalam sosialisasi, seperti; belajar memenuhi aturan kelompok, belajar bertanggung jawab, belajar bersaing secara sehat. Karakteristik ini memungkinkna seorang guru untuk merancang model pembelajaran yang memungkinkan anak bermain dan belajar dalam bentuk kelompok. 
Salah satu jenis model pembealajaran yang mengaplikasikan games didalamnya adalah pembelajaran kooperatif tipe Team Games Tournament (TGT). Slavin (2005:163) menyatakan bahwa TGT menggunakan turnamen akademik, menggunakan kuis dengan sistem skor individu. Pebelajar akan berlomba sebagai wakil tim mereka dengan anggota tim lain yang memiliki kapasitas akademik yang setara.

Untuk menyelesaikan masalah tersebut diperlukan perlu pengembangan buku teks tematik model menggunakan multimedia yang memuat pendidikan karakter sehingga kognitif yang berkembang seiring dengan karakter yang baik. Buku teks yang inovatif dapat memfasilitasi pembelajaran dengan berbagai tipe pebelajar dan dilengkapi dengan games dan turnamen yang dapat membuat anak belajar sambil bermain

Menurut Prastowo (2011: 17) buku teks adalah seperangkat materi yang disusun secara sistematis secara tertulis yang menampilkan sosok utuh dari kompetensi yang akan dikuasai siswa dan digunakan dalam proses pemebelajaran sehingga mencapai tujuan pembelajaran. Tematik merupakan salah satu pendekatan pembelajaran yang bersifat holistik. Berdasarkan Undang-Undang Nomor 20 Tahun 2013 Pasal 6 ayat 4 tentang Sistem Pendidikan Nasional menjelaskan bahwa pelaksanaan pendidikan secara holistik dimaksudkan bahwa proses pembelajaran antar kelompok mata pelajaran bersifat terpadu dalam mencapai standar kompetensi yang ditetapkan. Pembelajaran tematik adalah pembelajaran yang tidak menggunakan "nama-nama disiplin ilmu" sebagai nama mata pelajaran tetapi menggunakan tematema tertentu Yani (2013:114). Tema tersebut merupakan pengait dari sejumlah pokok bahasan dalam mata pelajaran atau memadukan beberapa mata pelajaran sehingga pembelajar tidak perlu dibingungkan dengan batasanbatasan disipli akademik dari setiap mata pelajaran.

Buku teks tematik yang dikembangkan disusun dengan pengembangan karakter. Lickona (1992: 12-22) mendefinisikan pendidikan karakter sebagai upaya yang sungguh-sungguh untuk membantu seseorang memahami, peduli, dan bertindak dengan landasan nilai-nilai etis. Nilai-nilai karakter yang dikembangkan meliputi; jujur, peduli, disiplin, tanggung jawab dan sopan.

Teams Games Tournamen (TGT) dikembangakn oleh David DeVries dan Keith Edwards, yang merupakan metode pembelajaran pertama dari Johns Hopkins yang pertama (Nur, 2011:7). Dalam sintak pembelelajaran TGT terdapat empat fase yang harus dilakukan, yaitu: (1) presentasi materi, (2) tim, (3) game, dan (4) turnamen. TGT memiliki dimensi kegembiraan yang diperoleh dari penguatan permaianan. Teman satu tim akan saling membantu dalam mempersiapkan diri untuk permainan dengan mempelajari lembar kegiatan dan menjelaskan masalah-masalah satu sama lain, tetapi ketika peserta didik bermain dalam game peserta didik lain tidak boleh membantu, sehingga telah terjadi tanggungjawab individual.

Multimedia adalah pengkolaborasian beebrapa media pembelajaran yang dipakai bersama-sama untuk mengoptimalkan kegiatan belajar mengajar. Penggunaan multimedia bertujuan untuk memfasilitasi kebutuhan peserta didik dalam belajar sesuai dengan gaya belajar pebelajar. DePotter \& Hernachi (2002:78) gaya belajar ada tiga karakteristik yaitu : visual (belajar dengan cara melihat), auditori (belajar dengan cara mendengar), dan kinestetik (belajar dengan cara bergerak, bekerja, dan menyentuh).

Berdasarkan rumusan masalah di atas, maka tujuan dari penelitian ini sebagai berikut. (a) mendeskripsikan proses pengembangan buku teks tematik berbasis karakter dengan multimedia sebagai penunjang model TGT; (b) mendeskripsikan kualitas pengembangan buku teks tematik berbasis karakter dengan multimedia sebagai penunjang model TGT; (c) mendeskripsikan impelmentasi pengembangan buku teks tematik berbasis karakter dengan multimedia sebagai penujang model TGT.

\section{TINJAUAN PUSTAKA}

Penelitian yang relevan dengan penelitian ini dikategorikan berdasarkan pengembangan buku teks tematik, pendidikan karakter, multimedia, dan model TGT dijelaskan sebagai berikut: penelitian yang dilakukan oleh Rosyidah Umami Octavia (2015) berjudul “ Pengembangan Buku Teks Kelas V Sekolah Dasar Berbasis Tematik Dengan Model Multiple Games”. Hasil penelitian pada validasi unsur ketepatan isi mendapatkan nilai rata-rata $91,6 \%$, unsur ketepatan penyajian mendapat nilai rata-rata $92,5 \%$. Sedangkan pada unsur ketepatan kebahasaan mendapat nilai rata-rata $89 \%$ dan unsur ketepatan penyajian mendapat nilai rata-rata $91,6 \%$ sehingga dapat dikatakan buku ajar yang dikembangkan sangat berkualitas.

Peneliitan selanjutnya dilakukan oleh Ummi Fitrah (2014) berjudul "Pengembangan Buku Teks Bahasa Indonesia Tematik Integratif Berbasis Budaya Madura Dengan Menggunakan Model Pembelajaran Kooperatif Untuk Siswa Kelas IV Sekolah Dasar”. Hasil penelitian yang diperoleh kelayakan isi dan kebahasaan mendapat nila rata-rata $100 \%$. Sedangkan kelayakan penyajian dan kegrafikaan secara berturut-turut memperoleh nilai rata- 
rata $98 \%$ dan $90 \%$ sehingga dapat diaktakan buku teks yang dikembangkan sangat berkualtas.

Penelitan tentang pengembangan karater yang dilakuakn oleh Mufidah (2014) berjudul “ Perkembangan Karakter Siswa Dalam Pembelajaran Matematika Di Kelas IV Sekolah Dasar". Hasil penelitian pada indikator pengetahuan moral siswa berada pada angka 2,7 dan terus meningkat pada pertemuan pertama yakni 3,0; pertemuan kedua 3,2; dan pertemuan ketiga 3,3.

\section{METODE}

Jenis penelitian ini adalah penelitian pengembangan (development reseacrh). Desain penelitian pengembangan buku teks diadaptasi dari The Four D Models atau sering disebut dengan 4-D yang dikembangkan oleh Thiagarajaan dan Semmel (1974:3). The Four D Models terdiri dari beberapa tahap; diantaranya adalah tahap pendefinisisan (define), tahap perancangan (design), pengembangan (develop), dan tahap penyebaran (disseminate). Dalam penelitian ini pengembangan buku teks diadaptasi hanya sampai pada tahap develop (pengembangan), buku teks yang dikembangakn hanya digunakan pada sekolah ujicoba, tanpa disebar pada sekolah lain.

Rancangan penelitian ini dimulai dengan melakukan define yakni tahap pendefinisian yang meliputi; analisis awal akhir, analisis siswa, analisis tugas, analisis konsep dan analisis tujuan pembelajaran. Tahap design yakni tahap perencanaan menghasilkan draf I buku teks kemudian divalidasi oleh tim ahli. Buku teks I direvisi sesuai dengan masukan dan saran tim ahli. Hasil dari revisi buku teks II kemudian di uji cobakan. Subjek dalam penelitian ini adalah 28 siswa dan satu guru kelas V SDN Megaluh Jombang Surabaya.

Prosedur penganalisisan data untuk kualitas produk dan penggunaan buku teks menggunakan rumus:

$$
\mathrm{P}(\%)=\frac{\text { jumian skor yang arperoien }}{\text { Shor makrimal }} \times 100 \%
$$

(Arikunto, 2006:40)

Setelah dilakukan uji coba terbatas, masukan dan saran pengguna digunakan untuk merevisi draf II buku teks hasil dari revisi disebut draf III buku teks. Draf III buku teks digunakan untuk uji coba luas. Masukan dan saran ketika menggunakan draf III buku teks digunakan untuk revisi. Hasil resivi adalah hasil final buku teks.

\section{HASIL DAN PEMBAHASAN}

Berdasarkan hasil validasi draf I buku teks komponen kelayakan materi memperoleh skor 28 dengan persentase $87.5 \%$ dan termasuk dalam kategori sangat layak. Komponen kelayakan kebahasaan memperoleh skor 23 dengan persentase $82.14 \%$ dan termasuk kategori layak. Komponen kelayakan penyajian memperoleh skor 33 dengan persentase 82.55 dan termasuk kategori layak. Sedangakan komponen kalayakan kegrafikaan 39 dengan persentase $81.25 \%$ dan termasuk kategori layak. Jumlah total keseluruhan dari keempat komponen kelayakan buku adalah 123 dengan persentase $83.36 \%$ perolehan persentase tersebut berkategori layak karena termasuk rentang $61-80 \%$.

Berdasarkan penilaian validasi draf II buku teks kelayakan materi dan penyajian memperoleh nilai rata-rata 4 dengan persentase $100 \%$. Nilai rata-rata kelayakan kebahasaan adalah 3,7 dengan persentase 96.42\%. Nilai rata-rata kelayakan kegrafikaan adalah 3.8 dengan persentase $95.83 \%$. Hasil penilaian validasi draf II buku teks mendapat jumlah skor 145 dengan persentase $97.97 \%$. Persentase tersebut dikategorikan sangat layak karena termasuk dalam rentang 85\% -- 100\%. Disimpulkan bahwa buku teks tematik berbasis karakter menggunakan multimedia sebagai penunjang model TGT sangat layak digunakan.

Penggunaan buku teks dilihat dari sudut pandang guru, aktivitas guru pada uji coba terbatas memperoleh persentase $89,5 \%$ termasuk dalam kategori sangat baik. Sedangkan aktivitas guru pada uji coba luas memperoleh persentase $96,87 \%$ termasuk dalam kategori sangat baik. Aktivitas guru mengalami peningkatan sebanyak 7,37\%. Sedangkan untuk respon guru pada uji coba terbatas memperoleh persentase $87,5 \%$. Persentase kategori ini termasuk sangat baik. Sedangkan respon guru pada uji coba luas memperoleh persentase $100 \%$. Persentase ini termasuk dalam kategori sangat baik. Respon guru mengalami peningkatan sebanyak $12,5 \%$.

Penggunaan buku teks dilihat dari sudut pandang siswa, aktivitas siswa pada uji coba terbatas memperoleh persentase $86,02 \%$ termasuk dalam kategori sangat baik. Sedangkan aktivitas siswa pada uji coba luas memperoleh persentase $97,05 \%$ termasuk dalam kategori sangat baik. Aktivitas siswa mengalami peningkatan sebanyak 11,03\%. Sedangkan untuk respon siswa pada uji coba terbatas memperoleh persentase $84,09 \%$. Persentase kategori ini termasuk sangat baik. Sedangkan respon siswa pada uji coba luas memperoleh persentase $96,10 \%$. Persentase ini termasuk dalam kategori sangat baik. Respon guru mengalami peningkatan sebanyak $12,01 \%$.

Hasil belajar siswa pada kegiatan pre test perolehan rata-rata uji coba terbatas adalah 66.25. Terdapat satu siswa yang mendapat nilai $\geq 70(\mathrm{KKM})$ dan tiga siswa dengan nilai belajar $\leq 70$ dengan persentase ketuntasan klasikal 33 
$\%$. Sedangkan pada kegaitan post test perolehanrata-rata uji coba terbatas adalah 85 . Semua siswa mendapat nilai $\geq 70$ (KKM) dengan persentase ketuntasan klasikal 100\%.

Berdasarkan hasil penelitian yang dIlakukan di SDN Megaluh Jombang dapat dinyatakan bahwa buku teks berbasis karakter menggunakan multimedia sebagai penunjang model TGT dapat membantu guru dalam menyampaikan materi pembelajaran kepada siswa. Materi yang terdapat dalam buku teks disesuaikan dengan lingkungan belajar siswa, sehingga materi yang disampaikan lebih mudah diterima oleh siswa. Hal tersebut sesuai dengan teori belajar Piaget yang berpendapat bahwa dalam mengajar seharusnya memperhatikan pengatahuan yang diperoleh siswa sebelumnya. Pada tahap ini siswa menggunakan pemikiran mereka secara logis, selain itu mereka juga menggunakan pengetahuan awal yang telah mereka dapat untuk memecahkan masalah. Oleh karena itu, peneliti mendesain buku teks dengan materi yang dekat dengan lingkungan belajar siswa sehingga siswa lebih mudah untuk menerima materi pembalajaran dan memecahkan permasalahan yang ada didalamnya karena siswa telah memiliki pengetahuan awal sebagai bekal untuk memecahkan masalah.

Berdasarkan hasil pengamatan yang dilakukan peneliti pada uji coba terbatas dan uji coba luas secara berturut-turut respon guru menunjukkan persentase $87.5 \%$ dan $100 \%$ kategori ini termasuk sangat baik karena terdapat pada rentang $80 \%-100 \%$. Begipula pada respon siswa pada uji coba teratas dan uji coba luas secara berturut-turut menunjukkan $84.09 \%$ dan $96.10 \%$ kategori ini teramasuk sangat baik karena terpadat pada rentang dapat $80 \%$-- $100 \%$.

Penelitian yang dilakukan oleh Ardan,S.Andam (2016) dengan judul "the development of biology teaching material based on the local wisdom of timorese to improve students knowledge and attitude of environment in caring the persevation of environmet". Pada hasil penemuan menyatakan bahwa untuk meningkatkan pengetahuan lokal dan kebiasaan yang baik kepada siswa dapat dilakukan melalaui pembelajaran kearifan budaya lokal. Buku teks yang menyajikan kearifan lokal dalam menyampaikan materi pembelajaran dapat mempermudah siswa untuk menyerap materi pelajaran yang diberikan. Hal ini dikarenakan semakin dekat materi yang disajikan dengan lingkungan belajar siswa, maka siswa akan lebih mudah untuk memahami permasalahan dan mencari jalan keluar untuk memecahkan permasalahan tersebut.

Berdasarkan hasil penelitian lembar let's do pada buku teks membantu dalam pembiasaan pendidikan karakter. Almerico, Gina (2014) dalam penelitiannya yang berjudul Building Character Trought Literacy with Children's Literature memaparkan keutamaan pengembangan dan implementasi pendidikan karakter yang diterapkan pada kurikulum tingkat sekolah dasar dan sekolah menengah adalah memasukkan muatan untuk menjadikan siswa lebih tanggung jawab, hormat, dan berkontribusi dalam kegiatan sosial. Keutamaan dari pendidikan karakter adalah membentuk pribadi warga negara yang baik dan bertanggungjawab. Untuk meralisasikan pendidikan karakter tidak cukup hanya mengajarkan kepada siswa tentang apa yang benar dan apa yang salah. Pembiasaan yang kuat tentang pendidikan karakter diperlukan untuk membantu siswa memahami hal yang benar dan salah (Purwanti, 2013). Orang tua mengasumsikan bahwa pendidikan karakter yang diperoleh anaknya di lingkungan sekolah sudah sangat baik dan guru telah berhasil menanamkan karakter tersebut. Pada realitanya pendidikan karakter ini tidak akan berhasil jika tidak ada kerjasama antara sekolah, guru, dan masyarakat.

Hal ini sependapat dengan Kusuma (2009) pendidikan karakter akan berjalan optimal jika mendapatkan dukungan dari keluarga, sekolah, dan masyarakat. Coestley, Kevin (2012) nilai karakter yang sebenarnya diajarkan dalam kurikulum dengan pengembangan yang berbeda menurut pembuat kontennya. Penilaian karakter yang mengikutsertakan orang tua sebagai pengawas dan penilai perkembangan karakter anak. Salah satu jenis pembelajaran karakter pada adalah melalui buku. Buku teks yang dikembangkan penulis disertai dengan kegiatan let's do pada akhir pembelajaran. Kegiatan let's do mengajak orang tua berperan aktif untuk memantau perkembangan karakter anak. Lembar kegiatan let's do memuat beberapa hal yang harus dikerjakan siswa sesuai dengan karakter yang dikembangkan. Orang tua bertugas untuk mengingatkan dan memberikan penghargaan berupa tanda cek list ketika anak telah melakukan kegiatan tersebut. Anggraini, Purwati (2013) dengan judul "the implementation of character education model based on empowerment theatre of primary school studentsthe implementation of character education model based on empowerment theatre of primary school students" menyatakan perlunya membuat lembar penilaian karakter agar orang tua mengetahui dan ikut serta pada penilaian tersebut sehingga turut serta mensukseskan program sekolah mengenai pendidikan karakter.

Berdasarkan hasil respon siswa menganai pembelajaran karakter pada pertanyaan ke-10 yaitu; apakah kamu sering menerapkan karakter yang baik dalam kehidupan sehari hari?. Pada uji coba terbatas 2 dari 4 
siswa menjawab iya dengan persentase pertanyaan 50\%. Hal ini menunjukkan bahwa implementasi kurikulum 2013 tentang pendidikan karater belum sepenuhnya dijalankan. Maka dari itu peneliti mendesain buku teks berbasis karakter agar dapat membantu guru, siswa, dan orang tua untuk mengoptimalkan pendidikan karakter. Setelah siswa menggunakan buku teks pada uji coba luas pertanyaan ke10 mendapat respon 24 siswa dari 28 dengan persentase pertanyaan $86 \%$. Hal ini menunjukkan adanya peningkatan $56 \%$ terhadap penerapan karakter siswa. Siswa menyatakan mampu menerapkan nilai-nilai karakter yang ada dalam buku dengan bekerja sama dengan orang tua.

Penggunaan multimedia dan model TGT yang digunakan dalam buku teks memberikan pengalaman belajar kepada guru dan siswa. Pada pengembangan buku teks ini, peneliti merasa perlu untuk menambahkan media pembelajaran baik dalam bentuk visual, audio, dan audio visual. Hal tersebut sependapat dengan DePotter \& Hernachi (2002:78) gaya belajar ada tiga karakteristik yaitu : visual (belajar dengan cara melihat), auditori (belajar dengan cara mendengar), dan kinestetik (belajar dengan cara bergerak, bekerja, dan menyentuh). Mengingat karakteristik belajar siswa berbeda-beda, penambahan multimedia dalam buku teks diharapkan mampu memfasilitasi guru dan siswa dalam proses pembelajaran. Roger (2014) dalam penelitiannya menyatakan bahwa kolaborasi penggunaan multimedia dapat menguatakan pesan pembelajaran pada pebelajar dengan menyentuh aspek kognitif, matakognitif, dan motivasi afektif. Mantiri, Franky (2014) berpendapat bahwa pebelajar dapat belajar dengan maksimal dan mendapatkan pemahaman yang lebih baik melalui gambar, vidoe, dan film.

Presentasi menggunakan multimedia menjaga fokus siswa menjadi lebih lama. Hal tersebut membantu siswa untuk lebih menganalisis dan mengolah informasi yang mereka dapat. Pembelajaran menggunakan buku teks, siswa terlihat sangat antusias dan lebih aktif mengikuti pembelajaran. Buku teks dilengkapi dengan tiga perintah untuk menggunkan multimedia yaitu; (1) let's see, sebagai instruksi penggunaan media visual yang meliputi: kartu kata, gambar, dan power point; (2) let's hear, sebagai instruksi penggunaan media audio yang meliputi: pesan verbal dan non verbal; (3) let's hear and see, sebagai instruksi penggunaan media audio visual yang meliputi: vidoe pembelajaran dan movie maker. Penggunaan multimedia dapat memberikan stimulus kepada siswa sehingga mereka lebih mudah dalam menerima materi.

Hal ini sependapat dengan Reeves (dalam Phing, Soo Belinda: 2007) yang menyatakan multimedia dapat menstimulasi lebih dari satu indera dalam satu waktu, dan melakukannya lebih, sehingga lebih banyak pengetahuan yang didapat dan ditangkap yang didapat. Berdasarkan hasil respon siswa menganai penggunaan multimedia pada pertanyaan ke-9 yaitu; apakah kamu senang dengan multimedia yang terdapat dalam buku teks tersebut. Pada uji coba terbatas 4 siswa menjawab iya dengan persentase pertanyaan $100 \%$. Hal ini menunjukkan bahwa siswa sangat menyukai penggunaan multimedia yang terdapat pada buku teks. Pada penggunaan buku teks pada uji coba luas pertanyaan ke-10 mendapat respon 28 siswa menjawab iya dengan persentase pertanyaan $100 \%$. Sedangkan hasil respon siswa menganai penggunaan model TGT pada pertanyaan ke-7 yaitu; apakah kamu suka dengan model TGT yang ada dalam buku teks. Pada uji coba terbatas 4 siswa menjawab iya dengan persentase pertanyaan $100 \%$. Sedangkan penggunaan buku teks pada uji coba luas pertanyaan ke-7 mendapat respon 28 siswa menjawab iya dengan persentase pertanyaan $100 \%$. Persentase termasuk termasuk rentang $90 \%$-- 100\% denngan katageri sangat menyukai. Hal ini menunjukkan bahwa siswa sangat menyukai penggunaan model TGT yang terdapat pada buku teks.

\section{SIMPULAN DAN SARAN}

Buku teks yang digunakan sebagain besar materinya harus memperhatikan karakteristik lingkungan pebelajar. Guru hendaknya dapat mengangkat kearifan lokal dalam pembelajaran. Sehingga proses pembelajaran lebih hidup, nyaman dan menyenangkan. Siswa mampu berperan aktif untuk melestarikan dan menjaga kearifan lokal derahnya. Penanaman karakter pada siswa hendaknya dilakukan sejak dini. Peran aktif antara sekolah dan orang tua untuk mengamati, mengawasi, dan melaporkan perkembangan karakter anak siswa sangat diperlukan. Melalui kegiatan pembiasaan berkarakter diharapkan siswa mampu memiliki pribadi yang baik. Guru hendaknya memperhatikan karakteristik siswa untuk menerima materi pembelajaran. Pemanfaatan multimedia dalam pembelajaran hendaknya dilakukan secara optimal untuk memenuhi kebutuhan siswa menerima materi pelajaran. Guru juga harus berinovasi dalam penggunaan model pembelajaran agar suasana belajar mengajar di kelas lebih kondusif.

\section{DAFTAR PUSTAKA}

Acuna, Santiago Roger. Mai 2014. Fostering Multimedia Learning with Collaborative Concept Mapping The Effect of Cognitif Aid on Perfomanced and on Collaboration. Journal, Vol.3,No.2. doi:10.5430/ijhe.v3n2p141 
Albertus, Doni Koesoma. 2010. Pendidikan Karakter Strategi Mendidik Anak di Jaman Global. Jakarta:Pt. Grasindo

Almerico, Gina. Oktober 2014. Building Character through Literacy with Children's Literature. University of Tampa. Retrieved. fromhttp://www.aabri.com/copyright.html.

Anggraini, Purwati. July 2016. The Implementation of Character Education Model Based on Empowerment Theatre for Primary School Students. Journal of education and practice. Volume 7,No.1. 2222-1735. Retrieved fromwww.iiste.org.

Ardan, Andam. July 2016. The Development ff Biology Teaching Based On the Local Wisdom of Timorese To Improve Students Knowledge and Attitude of Environment In Caring the Persevation of Environment. Vol.5,No3. doi:10.5430/ijhe.v5n3p190. Retrieved fromhttp://dx.doi.org/10.5430/ijhe.v5n3p190.

Arikunto, Suharsimi. 2006. Prosedur Penelitian: Suatu Pendekatan Praktik. Jakarta: .Rineka Cipta

Coestley, Kevin, Ph.D. 2012. Character Education: A Growing Need in American Schools. Arkanas Tech University

De Potter, Bobby dan Hernachi, Mike. 2001. Quantum Learning. Membiasakan Belajar Nyaman dan Menyenangkan. Bandung: Kaifa

Franky, Mantiri. 2014. Multimedia and Technology in Learning. Universal Journal of Education Research 2(9):589-592. Doi:10.13189/ujer.2014.020901. Retrieved. fromhttp://www.hrpub.org.

Komalasari, Kokom. 2010. Pembelajaran Konstektual Konsep dan Aplikasi. Bandung: Refika Aditama

Kraishan, Osama. Februari 2016. Evaluating og the Third Class Science Text Book from the Teacher's Perpsektive at Madaba Municipality. Doi:10.5539/ies/v9n3p123. Retrieved fromhttp://dx.doi.org/10.5539/ies.v9n3p123.

Kusuma, Dharma. 2011. Pendidikan Karakter Kajian Teori dan Praktik di Sekolah. Bandung: Remaja Rosdakarya

Nunan,D. 1991. Language Teaching Methodology. London: Prentice Hall Internasional

Nur, Mohamad. 2011. Model Pembelajaran Kooperatif. Surabaya: Pusat Sains dan Matematika Sekolah Unesa

Peraturan Menteri Pendidikan Nasional Republik Indonesia Nomor 2 Tahun 2008, Buku, (Jakarta:
Departemen Pendidikan Nasional, 2008) Halaman 110

Slavin, Robert. E. 2005. Cooperativi Learning. Teori, Riset dan Praktik (terjemahan). Bandung: Nusa Media.

Soo Phing, Belinda. Oktober 2007. Interctive Multimedia Learning: Student Attitudes and Learning Impact in an Animation Course. 1303-6521.

Thiagarajan, S.: Semmel, D.S. 1974. Instruction Development For Training Teacher of Exceptional Children: A Sourcebook. Indiana: Indiana University. Google Books Diunduh 6 Mei 2016

Thomas Lickona. 1992. Educating For Character: How Our School Can Teach Respect Anf Responbility. New: York: Bantan

Tim Penyusun Kemendikbud. 2013. Dokumen Kurikulum 2013 Kompetensi Dasar Sekolah Dasar (Sd)/ Madrasah Ibtidaiyah (Mi). Jakarta: Kemendikbud

Yani, Ahmad. 2013. Mindset Kurikulum 2013. Bandung: Alfabeta. 